\title{
Survival, Elongation, and Elevated Tolerance of Salmonella enterica Serovar Enteritidis at Reduced Water Activity
}

\author{
JASPER KIEBOOM, $\dagger$ HARSHI D. KUSUMANINGRUM, $\$$ MARCEL H. TEMPELAARS, WILMA C. HAZELEGER, \\ TJAKKO ABEE, AND RIJKELT R. BEUMER*
}

\author{
Laboratory of Food Microbiology, Department of Agrotechnology and Food Sciences, Wageningen University, P.O. Box 8129, \\ 6700 EV Wageningen, The Netherlands
}

MS 05-578: Received 15 November 2005/Accepted 27 May 2006

\begin{abstract}
Growing microorganisms on dry surfaces, which results in exposure to low water activity $\left(\mathrm{a}_{\mathrm{w}}\right)$, may change their normal morphology and physiological activity. In this study, the morphological changes and cell viability of Salmonella enterica serovar Enteritidis challenged to low $\mathrm{a}_{\mathrm{w}}$ were analyzed. The results indicated that exposure to reduced $\mathrm{a}_{\mathrm{w}}$ induced filamentation of the cells. The amount of filamentous cells at $a_{w} 0.94$ was up to $90 \%$ of the total number of cells. Surviving filamentous cells maintained their membrane integrity after exposure to low $\mathrm{a}_{\mathrm{w}}$ for 21 days. Furthermore, cells prechallenged to low $\mathrm{a}_{\mathrm{w}}$, obtained with an ionic humectant, demonstrated higher resistance to sodium hypochlorite than control cells. These resistant cells are able to survive disinfection more efficiently and can therefore cause contamination of foods coming in contact with surfaces. This points to the need for increased attention to cleaning of surfaces in household environments and disinfection procedures in processing plants.
\end{abstract}

Salmonella enterica serovar Enteritidis is the most important cause of Salmonella infections associated with the consumption of shelled eggs and poultry in Europe (25) and the United States (21). Cross-contamination directly from raw poultry to ready-to-eat products or indirectly through contaminated surfaces or niches in the household kitchen is the predominant mode of infection (9). In general, microorganisms often experience environmental stresses, such as nutrient starvation, osmotic shock, or temperature variation during transmission. The risks associated with cross-contamination of Salmonella Enteritidis from surfaces have been recognized because this microorganism has the ability to survive on stainless steel surfaces for hours or days, depending on the initial counts and the presence of food residues $(11,13)$. On surfaces, the cells are exposed directly to the air that may lead to water removal from the cells and adjustment of cytoplasmic solvent composition. Osmotic stress is one consequence of the initial stage of the air-drying of cells on surfaces $(4,20,22)$. Little is known about the response of Salmonella Enteritidis to dry or drying surfaces or surfaces with low water activity $\left(a_{w}\right)\left(\right.$ e.g., $\left.a_{w}<0.96\right)$ and the consequences of cellular ad-

\footnotetext{
* Author for correspondence. Present address: Laboratory of Food Microbiology, Department of Agrotechnology and Food Sciences, Wageningen University, P.O. Box 8129, 6700 EV Wageningen, The Netherlands. Tel: +31 (317) 4832 13; Fax: + 31 (317) 4849 78; E-mail: rijkelt.beumer@wur.nl.

$\dagger$ Present address: TNO Defence, Security and Safety, Business Unit Biological and Chemical Protection, P.O. Box 45, 2280 AA Rijswijk, The Netherlands.

$\ddagger$ Present address: Laboratory of Food Microbiology, Department of Food Technology and Human Nutrition, Faculty of Agricultural Engineering and Technology, Bogor Agricultural University, P.O. Box 220, Bogor 16002, Indonesia.
}

aptation on these surfaces to subsequent stress exposure, such as disinfection with sodium hypochlorite. Hypochlorite is generally used as chemical sanitizer because of its efficient action against a wide variety of microorganisms.

Mattick et al. (18) have shown that filamentous cells were formed by three wild-type strains of Salmonella Enteritidis in low $\mathrm{a}_{\mathrm{w}}$ broth. Lowering of $\mathrm{a}_{\mathrm{w}}$ values to 0.95 was achieved by addition of sucrose, glycerol, and sodium chloride $(\mathrm{NaCl})$. With the latter compound in the medium, the elongated cells appeared to be longer and more numerous (18). Furthermore, in another study, it has been shown that air-dried Salmonella cells become more tolerant to heat (12).

In this study, as a model for dry or drying surfaces, we investigated the morphological changes and cell viability of eight wild-type strains of Salmonella Enteritidis of different phage types after exposure to reduced $a_{w}$ at different temperatures. Agar surfaces with reduced $a_{w}$, obtained with $\mathrm{NaCl}$, were used as a model to study the response of bacteria to low $\mathrm{a}_{\mathrm{w}}$. The cross-protection against hypochlorite solutions as a result of prechallenge to reduced $\mathrm{a}_{\mathrm{w}}$ was studied in suspension tests.

\section{MATERIALS AND METHODS}

Bacterial strains and growth conditions. Six human isolates of Salmonella Enteritidis (1438 [phage type, PT, 13], 1439 [PT 4], 1444 [PT 25], 1391 [PT 21], 1389 [PT 1] and 1514 [PT $28]$ ), a chicken isolate (1138, PT 28), and a chicken meat isolate (1448, PT 4) were obtained from the National Institute of Public Health and the Environment, The Netherlands. The stock cultures were maintained at $-80^{\circ} \mathrm{C}$ in cryovials (Greiner Bio-One $\mathrm{GmbH}$, Frickenhausen, Germany) containing a stationary-phase culture in brain heart infusion (BHI; Difco, Becton Dickinson, Sparks, Md.) 
broth with $25 \%$ (vol/vol) glycerol (Fluka-Chemica, Buchs, Switzerland) and glass beads (diameter, $2 \mathrm{~mm}$; Emergo, Landsmeer, The Netherlands). Strains were precultured by transferring one glass bead to $10 \mathrm{ml}$ of BHI broth, followed by overnight incubation (20 to $22 \mathrm{~h}$ ) at $37^{\circ} \mathrm{C}$.

Survival in environments with reduced $\mathbf{a}_{\mathbf{w}}$. Survival at low $\mathrm{a}_{\mathrm{w}}$ was studied on tryptone soy agar (TSA; Oxoid, Basingstoke, UK) containing 4, 6, and 8\% $\mathrm{NaCl}$ (Merck, Darmstadt, Germany) in petri dishes, resulting in $\mathrm{a}_{\mathrm{w}}$ of $0.97,0.95$, and 0.94 , respectively. The $\mathrm{a}_{\mathrm{w}}$ was measured with a water activity meter (Novasina, $\mathrm{Zu}-$ rich, Switzerland) that was based on the relative vapor pressure. A total of $50 \mu \mathrm{l}$ of the appropriate dilutions of the preculture in peptone saline solution (PSS; $\mathrm{NaCl} 8.5 \mathrm{~g} /$ liter and neutralized bacteriological peptone [Oxoid] $1 \mathrm{~g} /$ liter) was applied on agar surfaces with a spiral inoculation apparatus (Eddy Jet; IUC, Barcelona, Spain), and the plates were sealed with parafilm to avoid evaporation of water during incubation at 25 and $37^{\circ} \mathrm{C}$. The colony counts were determined when the visible colonies were observed: after 2, 4, or 6 days, depending on the $a_{w}$ of the media and the incubation temperature. The recovery percentages were calculated as quotients of the colony counts at reduced $\mathrm{a}_{\mathrm{w}}$ and those on TSA without additional humectants.

On sterilized glass surfaces ( 2 by $7 \mathrm{~cm}^{2}$ ), $0.2 \mathrm{ml}$ of overnight culture of Salmonella Enteritidis diluted in fresh BHI broth to a concentration of approximately $10^{5} \mathrm{CFU} / \mathrm{ml}$ was applied and spread with a sterile loop, then incubated at 25 and $37^{\circ} \mathrm{C}$ in petri dishes. Microscopic examination of the glass surfaces with a Zeiss standard 20 light microscope was performed 24, 48, and $72 \mathrm{~h}$ after incubation.

Morphology changes. The morphology changes of the cells (i.e., cell elongation) were observed by viewing the cells from agar plates prepared on a microscopic slide with a $\times 100$ phase contrast objective of a Zeiss standard 20 light microscope. Images recorded by a Sony Hyper HAD, CCD-Iris/RGB color video camera. A Protocol computer system (Synoptics Ltd., Cambridge, UK) was used to generate digital photomicrographs. The percentages of elongated cells, calculated from the total cells, were determined by the direct microscopic count procedure with a BürkerTürk counting chamber (Schreck, Hofheim, Germany). Results are displayed as averages from two experiments with five observations for each experiment. Because under optimal growth condition Salmonella Enteritidis cells were found to be between 2 to 3 $\mu \mathrm{m}$ in length, cells longer than two times the maximal length (i.e., $6 \mu \mathrm{m}$ ) were considered to be elongated cells.

Cell viability. The cells grown at $\mathrm{a}_{\mathrm{w}} 0.95$ and $\mathrm{a}_{\mathrm{w}} 0.94$ and incubated for 6 days at $25^{\circ} \mathrm{C}$ were transferred with a sterile loop into an Eppendorf tube (Greiner Bio-One) containing $1 \mathrm{ml}$ of PSS. The cell suspensions were centrifuged (BHG-Hermle, Gosheim, Germany) at $4,000 \times g$ at $4^{\circ} \mathrm{C}$ for $5 \mathrm{~min}$, and the pellets were resuspended in PSS to a concentration ranging from 1.0 to $1.5 \times$ $10^{8} \mathrm{CFU} / \mathrm{ml}$. The culturability of these cells was determined on TSA and mannitol lysine crystal violet brilliant green agar (MLCB; Oxoid), a selective medium for isolation of Salmonella.

The membrane integrity of the cells grown at reduced $a_{w}$ was determined with LIVE/DEAD BacLight Bacterial Viability Kits (Molecular Probes, Inc., Eugene, Oreg.) according to the protocols provided with the kit. This kit uses mixtures of $3.34 \mathrm{mM}$ SYTO 9 green fluorescent nucleic acid stain and $20 \mathrm{mM}$ of the red fluorescent nucleic acid stain propidium iodide (PI). With a 1:1 mixture of the SYTO 9 and PI stains, bacteria with intact cell membranes stain fluorescent green, whereas bacteria with damaged membranes stain fluorescent red. The cell suspensions were mi- croscopically analyzed with an Axioskop epifluorescence microscope equipped with a $50 \mathrm{~W}$ mercury arc lamp, a fluorescein isothiocyanate filter set (excitation wavelength, 450 to $490 \mathrm{~nm}$; emission wavelength, $>515 \mathrm{~nm}$ ), a $\times 1001.3$-numerical aperture Plan-Neofluar objective lens, and a camera (Carl Zeiss, Oberkochen, Germany). Photomicrographs were made with simultaneous light and epifluorescence microscope, a low light intensity, a magnification of $\times 1,000$, and an exposure time of 15 to $45 \mathrm{~s}$ on Kodak 400 ASA color film. In these photomicrographs, both the SYTO 9 and PI-labeled cells could be counted. Depending on the number of cells, 10 to 20 microscopic fields were counted.

Flow cytometry. The cells grown at reduced $\mathrm{a}_{\mathrm{w}}$, labeled with BacLight bacterial viability kits, were analyzed with a FACSCalibur flow cytometer (Becton Dickinson Immunocytometry System, San Jose, Calif.) equipped with a $15 \mathrm{~mW}$ blue light at 488 $\mathrm{nm}$, air-cooled argon ion laser. The side scatter signal was used as a trigger signal. The green fluorescence from SYTO 9-stained cells was detected through a 515- to 545-nm band-pass filter (FL1 channel), and the red fluorescence of the PI signal was collected in the FL3 channel (>670 nm long-pass filter). FACSFlow solution (Becton Dickinson) was used as the sheath fluid. The cells were measured at a low flow rate corresponding to 150 to 500 cells per second, and 10,000 events were collected for further analysis. A combination of forward scatter (FSC) and side scatter (SSC) signals was used to discriminate bacteria from the background and to characterize the morphology of the cells. All signals were collected by logarithmic amplifications. Data from the flow cytometer were analyzed by WinMDI (Joseph Totter, Salk Institute for Biological Studies, La Jolla, Calif.; available at http:// facs.scripps.edu/software.html).

Cross-protection to sodium hypochlorite challenges. The cell suspensions were prepared from the population on TSA with reduced $\mathrm{a}_{\mathrm{w}}$ and incubated at $25^{\circ} \mathrm{C}$ for 6 days to a concentration of 1.0 to $1.5 \times 10^{8} \mathrm{CFU} / \mathrm{ml}$, as described for examination of the cell culturability. Sodium hypochlorite (Acros Organics, Morris Plains, N.J.) solutions were prepared at chlorine concentrations of $4.2 \mathrm{mM}(300 \mathrm{ppm})$ and $5.6 \mathrm{mM}(400 \mathrm{ppm})$. The available chlorine concentrations were confirmed by titration (1). The preparation of the solutions and the suspension tests was carried out following European Norm 1276 (4). Bovine serum albumin (3 g/liter from Sigma-Aldrich, Steinheim, Germany) was used as an interfering substance to simulate dirty conditions. The reductions of the $\log$ numbers were determined at 10, 30, and $60 \mathrm{~min}$ of exposure to hypochlorite.

Statistical analyses. Each experiment was carried out at least twice on different days, and no fewer than two replications were performed for each experiment. Except flow cytometry data, data analyses were performed on the statistical software package SPSS for Windows 95/98/NT/2000, release 10.1 (SPSS Inc., Chicago, Ill.). A $P$ value of $<0.05$ was considered to be statistically significant.

\section{RESULTS}

Survival in reduced $\mathbf{a}_{\mathbf{w}}$ environments. In BHI broth $\left(a_{w}\right.$ 0.999), all strains formed visible colonies 2 days after incubation at $37^{\circ} \mathrm{C}$ at $\mathrm{a}_{\mathrm{w}} 0.97$ and 0.95 , whereas at $25^{\circ} \mathrm{C}$, the colonies appeared after 4 and 6 days, respectively. Strikingly, at $\mathrm{a}_{\mathrm{w}} 0.94$ no separate colonies were formed, but a thin layer of bacterial growth appeared. The recovery percentages, calculated as quotients of the colonies at reduced $\mathrm{a}_{\mathrm{w}}$ and those on TSA without additional humectants, were 
TABLE 1. Percentages of elongated cells $(>6 \mu \mathrm{m})$ at reduced $a_{w}$ after 6 days at $25^{\circ} \mathrm{C}$, determined by direct microscopic counting ${ }^{a}$

\begin{tabular}{ccc}
\hline & \multicolumn{2}{c}{ Percentage of elongated cells at: } \\
\cline { 2 - 3 } Strain & $\mathrm{a}_{\mathrm{w}} 0.95$ & $\mathrm{a}_{\mathrm{w}} 0.94$ \\
\hline 1138 & $29 \pm 6$ & $88 \pm 4$ \\
1389 & $24 \pm 5$ & $94 \pm 2$ \\
1391 & $40 \pm 5$ & $90 \pm 3$ \\
1444 & $38 \pm 6$ & $94 \pm 2$ \\
1448 & $24 \pm 5$ & $93 \pm 2$ \\
1438 & $34 \pm 4$ & $82 \pm 6$ \\
1439 & $29 \pm 4$ & $87 \pm 3$ \\
1514 & $35 \pm 3$ & $90 \pm 6$ \\
\hline
\end{tabular}

${ }^{a}$ Data are expressed as average $\pm \mathrm{SD}$ percentages.

in a range of 70 to $95 \%$ at $\mathrm{a}_{\mathrm{w}} 0.97$, and 30 to $70 \%$ at $\mathrm{a}_{\mathrm{w}}$ 0.95 . The overall recovery at 25 or $37^{\circ} \mathrm{C}$ was not dependent on the temperature $(P=0.45)$ but was only affected by the $\mathrm{a}_{\mathrm{w}}(P=0.01)$.

Morphology changes. Microscopy revealed that all tested strains of Salmonella Enteritidis formed elongated cells (longer than $6 \mu \mathrm{m}$ ) at $\mathrm{a}_{\mathrm{w}} 0.95$ and $\mathrm{a}_{\mathrm{w}}$ 0.94. At $\mathrm{a}_{\mathrm{w}}$ 0.97, no elongated cells were found. Direct microscopic counting indicated that at $\mathrm{a}_{\mathrm{w}} 0.95$, the percentage of the elongated cells was between 24 and $40 \%$, and at $\mathrm{a}_{\mathrm{w}} 0.94$ between 82 and $90 \%$ of the total cell numbers (Table 1). Particularly at $25^{\circ} \mathrm{C}$ and $\mathrm{a}_{\mathrm{w}} 0.94$, elongated cells with a size of $50 \mu \mathrm{m}$ or more were found (Fig. 1). Microscopical analysis of cells in liquid low $\mathrm{a}_{\mathrm{w}}$ medium, obtained with $\mathrm{NaCl}$ and glucose (data not shown), both showed the formation of elongated cells. This suggested that reduced $\mathrm{a}_{\mathrm{w}}$ resulted in filamentation and that this was not due to surface effects or the presence of high $\mathrm{NaCl}$ concentrations.

Our study also indicated that when an aliquot of bacterial suspension in fresh BHI broth was applied on glass surfaces, elongated cells were microscopically observed after slow air-drying for $24 \mathrm{~h}$ at $37^{\circ} \mathrm{C}$ and for $48 \mathrm{~h}$ at $25^{\circ} \mathrm{C}$. The elongated cells were found on these glass surfaces in low percentages (approximately 3\% of the cell population), indicating that filamentation of the cells may occur on Sal- monella-contaminated wet surfaces after a slow-drying process.

Analysis of data obtained by flow cytometry indicated that cells challenged to $\mathrm{a}_{\mathrm{w}} 0.95$ showed slightly higher signals on FSC and SSC (Fig. 2B) compared with the control cells grown on TSA (Fig. 2A). A noticeable increase of FSC and SSC signals was observed in cell populations grown at $\mathrm{a}_{\mathrm{w}}$ 0.94, which resulted in a complete shift of a population on both detector signals (Fig. 2C). These findings indicated that particularly at $\mathrm{a}_{\mathrm{w}} 0.94$ cells with large dimensions were observed, which was confirmed by the microscopy analysis.

Cell viability. The culturability on TSA and MLCB of cells prechallenged at $\mathrm{a}_{\mathrm{w}} 0.95$ and 0.94 at $25^{\circ} \mathrm{C}$ for 6 days are shown in Figure 3. In a control experiment, we demonstrated equal colony counts on MLCB and TSA, indicating that the viability of cells was not affected by the selective agents present in MLCB.

Epifluorescence microscopy of the stressed cells revealed the existence of four subpopulations composed of viable short and elongated cells as well as nonviable short and elongated cells (Fig. 4). The viability was based on assessment of intact or damaged membrane of individual cells. Dead cells with damaged membrane accumulated PI and were stained fluorescent red. At $\mathrm{a}_{\mathrm{w}} 0.95$ at $25^{\circ} \mathrm{C}$, about 80 and $70 \%$ of the total number of the cells were still viable after 6 and 21 days, respectively. Among the elongated cells, the percentage of the viable cells was approximately $75 \%$ after 6 days and decreased to $50 \%$ after 21 days of exposure (Fig. 4). At $\mathrm{a}_{\mathrm{w}}$ 0.94, about $50 \%$ of the cell population lost their viability after 6 days. Exposure at $a_{w} 0.94$ resulted in more rapid loss of viability than at higher $a_{w}$. Furthermore, when the elongated cells were recovered in $\mathrm{BHI}$ broth and incubated at $37^{\circ} \mathrm{C}$, the majority of the filaments split up, and the separation was complete within approximately $3 \mathrm{~h}$, as was observed under the microscope (data not shown).

Figure 2 shows dot plots of events collected by flow cytometry of the control cells (D) and cells challenged at $\mathrm{a}_{\mathrm{w}} 0.94(\mathrm{E})$, subsequently stained with the BacLight kit. FL1 is a measure for green fluorescence of SYTO 9-stained cells. The control cells demonstrated low signals on SSC
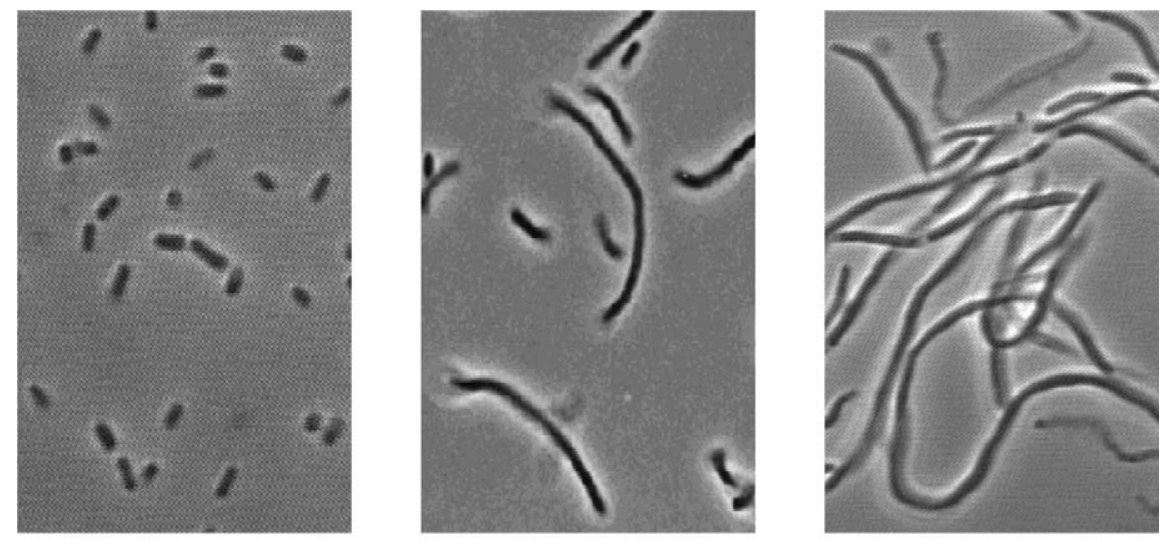

FIGURE 1. Impact of reduced water activities on cell morphology of Salmonella Enteritidis strain 1448. (A) Control cells, (B) cells at $a_{w} 0.95$, and $(C)$ cells at $a_{w} 0.94$, after 6 days at $25^{\circ} \mathrm{C}$.
A

B
$\mathrm{C}$ 
FIGURE 2. Flow cytometry analysis of low $a_{w}$ stressed Salmonella Enteritidis strain 1448 after 6 days at $25^{\circ} \mathrm{C}$. Forward side scatter (FSC) versus side scatter signals (SSC) of (A) cells grown on TSA, (B) cells challenged at $a_{w} 0.95$ and $(C)$ at $a_{w} 0.94$, and green fluorescence (FL1) versus side scatter signals (SSC) of (D) cells grown on $T S A$, and (E) cells challenged at $a_{w} 0.94$.
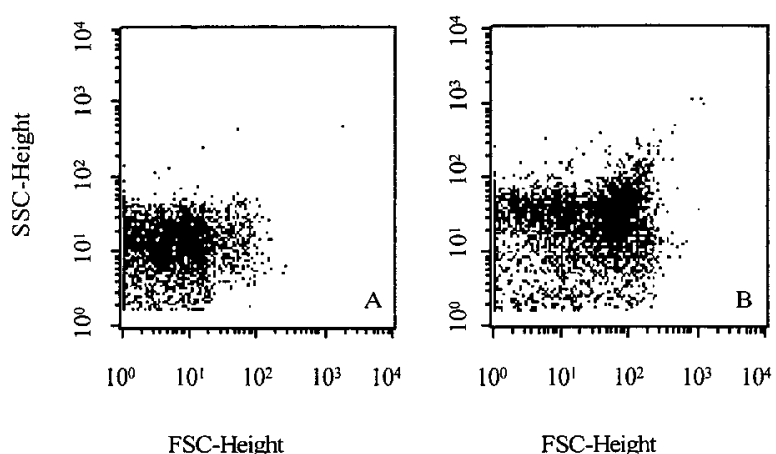

FSC-Height
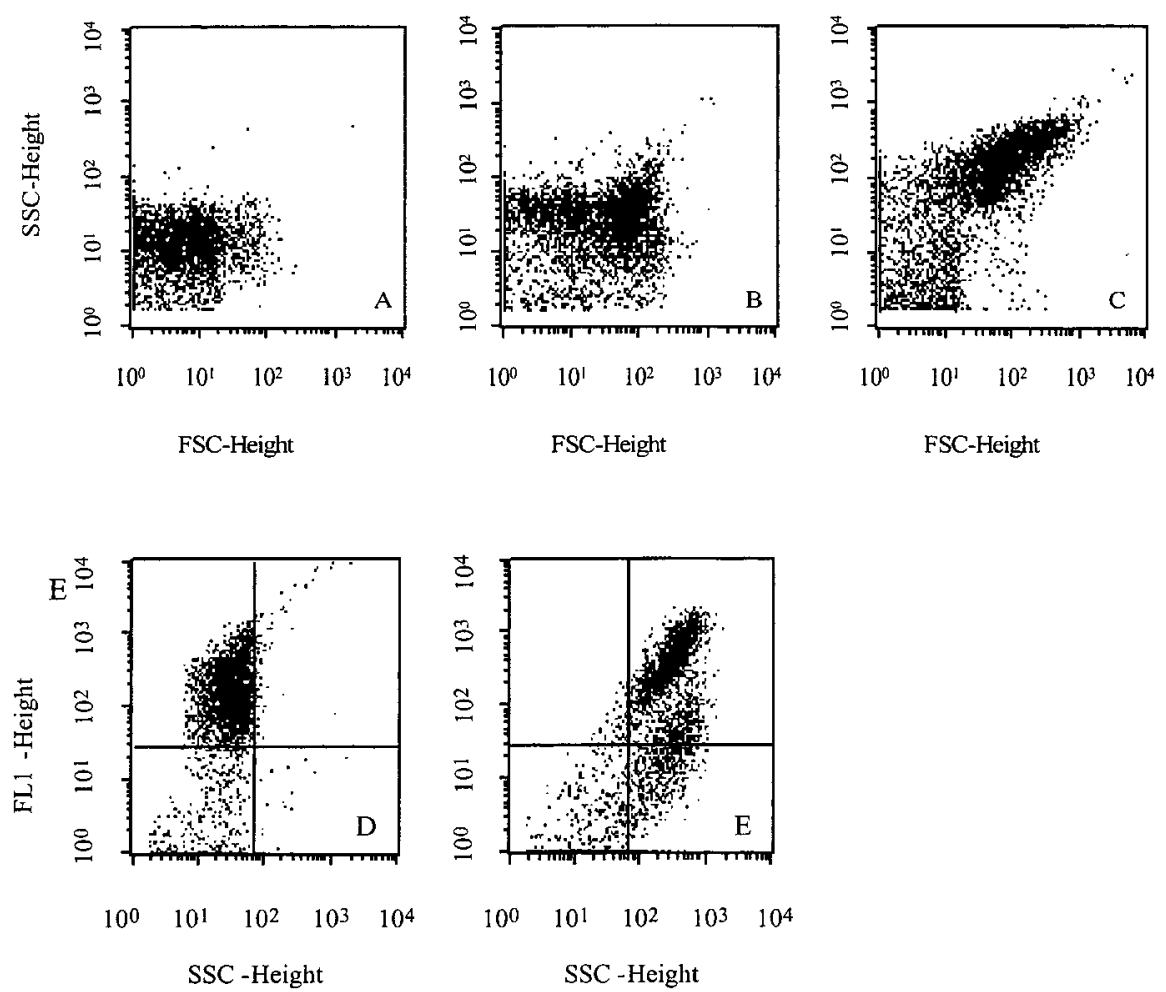

with high signals on FL1, indicating that almost all cells were viable. Cells challenged at $\mathrm{a}_{\mathrm{w}} 0.94$ revealed a shift in population with higher SSC signals, indicating formation of elongated cells as also shown before in Figure 2C, and this consisted of two populations (approximately 50\% of the total counts for each population) either with high and low signals on FL1 (Fig. 2E). Moreover, the population with the low FL1 signals also displayed high FL3 signals (data not shown), indicating that these PI-stained cells are dead. These results confirm the findings obtained by the fluorescence microscopy analysis, which indicated that after exposure at 0.94 for 6 days at $25^{\circ} \mathrm{C}$, the majority of the cells were elongated, and approximately $50 \%$ of the cells were viable.

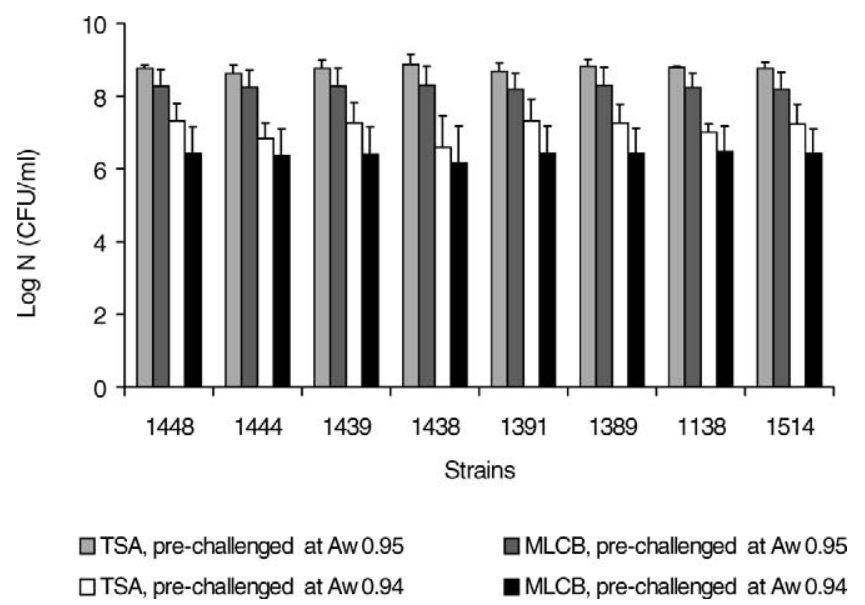

FIGURE 3. Culturability on TSA and MLCB agar of Salmonella Enteritidis strains prechallenged for 6 days at $25^{\circ} \mathrm{C}$ at $a_{w} 0.95$ and $a_{w} 0.94(\mathrm{n}=2)$.
Cross-protection to sodium hypochlorite. The tolerance of cells grown on TSA (control) and prechallenged at reduced $\mathrm{a}_{\mathrm{w}}$, obtained with $\mathrm{NaCl}$, to hypochlorite solutions at $25^{\circ} \mathrm{C}$ is shown in Figure 5. Experiments showed that the $\mathrm{NaCl}$ downshock by serial dilutions in PSS did not influence the results (data not shown). At a chlorine concentration of $300 \mathrm{ppm}(4.2 \mathrm{mM})$, a $3-\log$ reduction was observed for control cells after $60 \mathrm{~min}$ of exposure. Cells that were

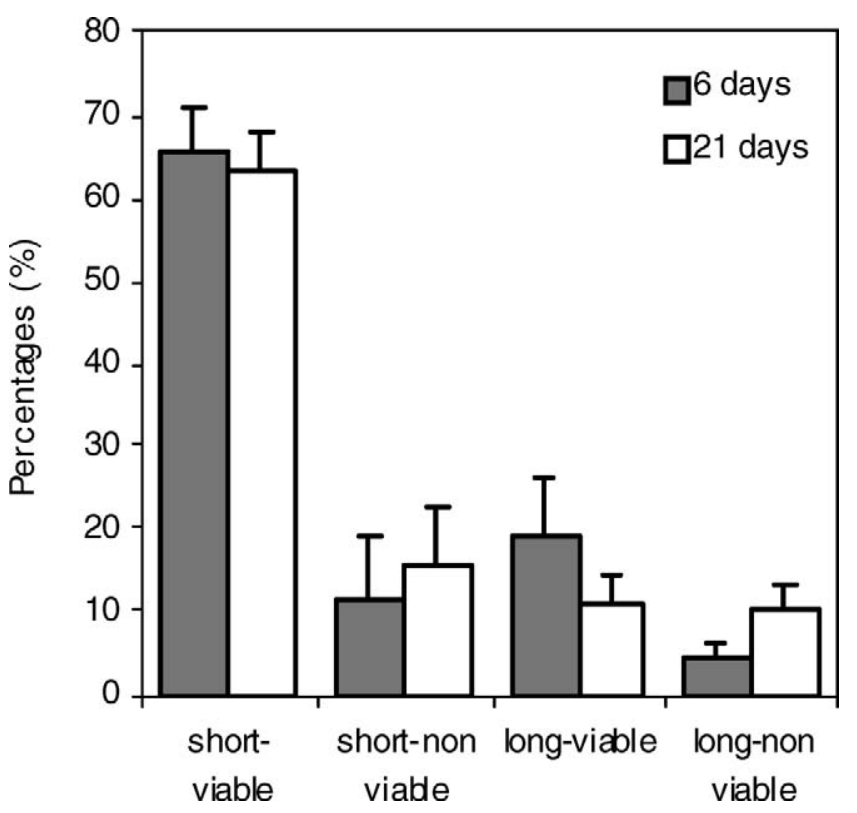

FIGURE 4. Viability of Salmonella Enteritidis strain 1448 challenged at $a_{w} 0.95$ at $25^{\circ} \mathrm{C}$, determined by direct microscopy counting after staining with Live/Dead BacLight viability kit $(\mathrm{n}=2)$. Cells longer than $6 \mu \mathrm{m}$ were considered as elongated cells. 

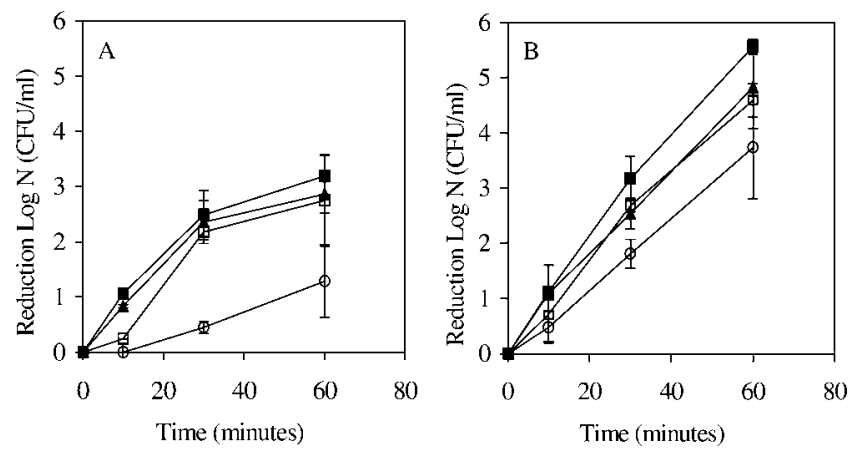

FIGURE 5. Tolerance to sodium hypochlorite of Salmonella Enteritidis strain 1448 at (A) $300 \mathrm{ppm}(4.2 \mathrm{mM})$ and (B) $400 \mathrm{ppm}$ $(5.6 \mathrm{mM})(\mathrm{n}=3) . \boldsymbol{\square}$, Control cells; $\boldsymbol{\Delta}$, cells prechallenged at $a_{w}$ 0.97; $\bigcirc$, cells prechallenged at $a_{w}$ 0.95; $\square$ cells prechallenged at $a_{w} 0.94$.

prechallenged to $\mathrm{a}_{\mathrm{w}} 0.95$ were the most tolerant to the treatment, followed by the cells challenged to $\mathrm{a}_{\mathrm{w}} 0.94$ and 0.97 .

At 400 ppm $(5.6 \mathrm{mM})$, a higher killing efficiency was found with the same trend. After $60 \mathrm{~min}$ of exposure, more than a 5-log reduction was observed for the control cells, whereas cells prechallenged to $\mathrm{a}_{\mathrm{w}} 0.95$ were reduced by approximately $3 \log$ units. The cells that were prechallenged to $\mathrm{a}_{\mathrm{w}} 0.97$ and 0.94 decreased by approximately 4.5 $\log$ units. Overall, the cells challenged to reduced $\mathrm{a}_{\mathrm{w}}$ demonstrated better tolerance to hypochlorite than the control cells.

\section{DISCUSSION}

In this study, the responses of eight wild-type strains of Salmonella Enteritidis to reduced $\mathrm{a}_{\mathrm{w}}$ environments were analyzed. Challenge at $\mathrm{a}_{\mathrm{w}} 0.95$ and 0.94 resulted in cell elongation of all tested Salmonella Enteritidis strains.

Mattick et al. (19) demonstrated that filamentous salmonellas contained regularly spaced nucleoids, which indicated that cells were probably blocked in septation. It is conceivable that the cells elongation resulted from inactivation or inhibition of cell division proteins, which in turn blocks the septation during the cell division (16, 23). It has been reported that FtsZ is by far the best-conserved cell division protein; it is also present in most species of bacteria $(16,23)$. Next to FtsZ, when any one of the cell division proteins in Escherichia coli, including FtsA, FtsI, FtsK, FtsL, FtsN, FtsQ, FtsW, and ZipA, is nonfunctional or absent, cells grow without dividing, which leads to the formation of filaments $(3,6)$.

Because not all cells were elongated, as was particularly observed at $\mathrm{a}_{\mathrm{w}}$ 0.95, the response of Salmonella Enteritidis strains to $\mathrm{a}_{\mathrm{w}}$ reduction occurs at the level of the individual cell. Booth (2) suggested that response to stress largely takes place at the single cell level and can lead to heterogeneity in a bacterial population. This heterogeneity is a recognized property of bacterial populations and allows adaptation to a diversity of niches. Any protein that is required for survival is capable of contributing to the heterogeneity (2).

Cellular parameters essential to survival under stress conditions are the integrity of the cell membrane, mainte- nance of the folding of proteins, and the integrity of the DNA $(2,5)$. Discrimination between intact and permeable cells by fluorescent stains has been used in many studies on viability of bacteria (6). Examining the cell viability by means of fluorescent techniques highlighted the heterogeneity of Salmonella Enteritidis populations in response to challenge to low $\mathrm{a}_{\mathrm{w}}$ because both viable and nonviable short and elongated cells were observed. The filamentation of the cells resulted in higher signals on FSC and SSC by flow cytometry. FSC light is laser light diffracted around the cells and is related to cell surface area. SSC light is reflected and refracted laser light; is related to the internal complexity or granularity of a cell (6). A large population of cells (i.e., 10,000 events) was measured by flow cytometry, which offered substantial information on the morphological heterogeneity of this particular bacterial population, allowing sorting and subsequent characterization of filamentous cells in future experiments.

Studies have demonstrated the fact that Salmonella cells adapted to certain stress conditions show cross-protection against other stresses $(17,24)$. In this study, we investigated the effect of sodium hypochlorite on cells prechallenged to low $\mathrm{a}_{\mathrm{w}}$ obtained with an ionic humectant. When mixed with water, sodium hypochlorite dissociates and forms hypochlorous acid $(\mathrm{HOCl})$, an active form of chlorine. $\mathrm{HOCl}$ is an effective disinfectant partly because most microorganisms do not posses specific enzymes for detoxification of $\mathrm{HOCl}$, like they do for other oxidants such as reactive oxygen species (14). This study indicated that the cells prechallenged to low $\mathrm{a}_{\mathrm{w}}$ show better tolerance against sodium hypochlorite than the control cells with ionic humectant. Cross-protection to hypochlorite may be conferred by the expression of the stress sigma factor rpoS and the subsequent synthesis of stress-related proteins in the cells exposed to low $\mathrm{a}_{\mathrm{w}}(8)$. Moreover, the addition of the ionic humectant $\mathrm{NaCl}$ may induce the accumulation of compatible solutes such as betaine that may confer protection against the detrimental effects of sodium hypochlorite by maintaining cellular protein conformation and enzyme activities and supporting cell membrane integrity $(7,10$, 15).

The survival of Salmonella Enteritidis at reduced $\mathrm{a}_{\mathrm{w}}$ as low as 0.94 -increases the risk of cross-contamination because these tolerant cells can come into contact with foodstuffs placed on these surfaces. In this study, we observed that the filamentation of the cells resulted in an increase of the optical density in broth without apparent increase in colony-forming units (data not shown), indicating that filamentous cells form single colonies on plates. However, when these elongated cells were recovered under favorable conditions, the filaments could split up and form numerous single cells. The possible presence of elongated cells on surfaces should be considered a potential infection risk because these filaments are viable for several days and can rapidly split up under favorable conditions in foodstuffs, resulting in a large number of viable cells. Furthermore, the existence of a population tolerant to hypochlorite after challenge to low $\mathrm{a}_{\mathrm{w}}$ poses an important risk for public health. These cells can survive disinfection in processing 
plants or on household surfaces more efficiently. Therefore, increased attention should be paid to the cleaning and disinfection procedures used on surfaces in these environments.

\section{ACKNOWLEDGMENTS}

We thank Kaouther Ben-Amor for her valuable comments on flow cytometry assessments. This project was partly funded by the Health, Safety and Sustainability program of The Netherlands Organization for Health Research and Development.

\section{REFERENCES}

1. Bender, D. F., J. P. Gould, J. D. Johnson, and A. T. Palin. 1985. Determination of inorganic nonmetallic constituents: chlorine (residual). In A. E. Greenberg, R. R. Trussell, and L. S. Clesceri (ed.), Standard methods for the examination of water and wastewater, 16th ed. American Public Health Association, Washington, D.C.

2. Booth, I. R. 2002. Stress and the single cell: intrapopulation diversity is a mechanism to ensure survival upon exposure to stress. Int. J. Food Microbiol. 78:19-30.

3. Chen, J. C., and J. Beckwith. 2001. FtsQ, FtsL and FtsI require FtsK, but not FtsN, for co-localization with FtsZ during Escherichia coli cell division. Mol. Microbiol. 42:395-413.

4. Comité Européen de Normalisation, European Committee for Standardization (CEN). 1997. European Norm 1276. Chemical disinfectants and antiseptics-quantitative suspension test for the evaluation of bactericidal activity of chemical disinfectants and antiseptics used in food, industrial, domestic, and institutional areas-test method and requirements (phase 2, step 1). British Standard Institute, London.

5. Csonka, L. N. 1989. Physiological and genetic responses of bacteria to osmotic stress. Microbiol. Rev. 53:121-147.

6. Davey, H. M., and D. B. Kell. 1996. Flow cytometry and cell sorting of heterogeneous microbial populations: the importance of singlecell analyses. Microbiol. Rev. 60:641-649.

7. Diamant, S., D. Rosenthal, A. Azem, N. Eliahu, A. P. Ben-Zvi, and P. Goloubinoff. 2003. Dicarboxylic amino acids and glycine-betaine regulate chaperone-mediated protein-disaggregation under stress. Mol. Microbiol. 49:401-410.

8. Dodd, C. E., and T. G. Aldsworth. 2002. The importance of RpoS in the survival of bacteria through food processing. Int. J. Food Microbiol. 74:189-194.

9. Dufrenne, J., W. Ritmeester, E. Delfgou-van Asch, F. van Leusden, and R. de Jonge. 2001. Quantification of the contamination of chicken and chicken products in The Netherlands with Salmonella and Campylobacter. J. Food Prot. 64:538-541.

10. Gutierrez, C., T. Abee, and I. R. Booth. 1995. Physiology of the osmotic stress response in microorganisms. Int. J. Food Microbiol. 28:233-244.
11. Humphrey, T. J., E. Slater, K. McAlpine, R. J. Rowbury, and R. J. Gilbert. 1995. Salmonella-Enteritidis phage type-4 isolates more tolerant of heat, acid, or hydrogen-peroxide also survive longer on surfaces. Appl. Environ. Microbiol. 61:3161-3164.

12. Kirby, R. M., and R. Davies. 1990. Survival of dehydrated cells of Salmonella Typhimurium LT2 at high-temperatures. J. Appl. Bacteriol. 68:241-246.

13. Kusumaningrum, H. D., G. Riboldi, W. C. Hazeleger, and R. R. Beumer. 2003. Survival of foodborne pathogens on stainless surfaces and cross-contamination to foods. Int. J. Food Microbiol. 25:227236.

14. Leyer, G. J., and E. A. Johnson. 1997. Acid adaptation sensitizes Salmonella typhimurium to hypochlorous acid. Appl. Environ. Microbiol. 63:461-467.

15. Lloyd, A. W., J. A. Baker, G. Smith, C. J. Olliff, and K. J. Rutt. 1992. A comparison of glycine, sarcosine, N,N-dimethylglycine, glycinebetaine and $\mathrm{N}$-modified betaines as liposome cryoprotectants. $J$. Pharm. Pharmacol. 44:507-511.

16. Margolin, W. 2000. Themes and variations in prokaryotic cell division. FEMS Microbiol. Rev. 24:531-548.

17. Mattick, K. L., F. Jorgensen, J. D. Legan, M. B. Cole, J. Porter, H. M. Lappin-Scott, and T. J. Humphrey. 2000. Survival and filamentation of Salmonella Enteritidis PT4 and Salmonella enterica serovar Typhimurium DT104 at low water activity. Appl. Environ. Microbiol. 66:1274-1279.

18. Mattick, K. L., F. Jorgensen, J. D. Legan, H. M. Lappin-Scott, and T. J. Humphrey. 2000. Habituation of Salmonella spp. at reduced water activity and its effect on heat tolerance. Appl. Environ. Microbiol. 66:4921-4925.

19. Mattick, K. L., L. E. Phillips, F. Jorgensen, H. M. Lappin-Scott, and T. J. Humphrey. 2003. Filament formation by Salmonella spp. inoculated into liquid food matrices at refrigeration temperatures, and growth patterns when warmed. J. Food Prot. 66:215-219.

20. O'Byrne, C. P., and I. R. Booth. 2002. Osmoregulation and its importance to food-borne microorganisms. Int. J. Food Microbiol. 74: 203-216.

21. Olsen, S. J., L. C. MacKinon, J. S. Goulding, N. H. Bean, and L. Slutsker. 2002. Surveillance for foodborne disease outbreaks-United States, 1993-1997. MMWR surveillance summaries 49 (SS01). Available at: http://www.cdc.gov/mmwr/preview/mmwrhtml/ ss4901a1.htm. Accessed 25 July 2006.

22. Potts, M. 1994. Desiccation tolerance of prokaryotes. Microbiol. Rev. 58:755-805.

23. Rothfield, L., S. Justice, and J. Garcia-Lara. 1999. Bacterial cell division. Annu. Rev. Genet. 33:423-448.

24. Saby, S., P. Leroy, and J. C. Block. 1999. Escherichia coli resistance to chlorine and glutathione synthesis in response to oxygenation and starvation. Appl. Environ. Microbiol. 65:5600-5603.

25. Schmidt, K., and C. Tirado (ed.). 2001. WHO surveillance programme for control of foodborne infections and intoxications in $\mathrm{Eu}-$ rope, 7th report, 1993-1998. Federal Institute for Health Protection of Consumers and Veterinary Medicine, Berlin, Germany. 